\title{
A note on the system chemistry
}

\author{
Miloje M. Rakočević \\ University of Niš, Faculty of Sciences and Mathematics, Department of Chemistry, \\ Višegradska 33, 18000 Niš, Serbia
}

\begin{abstract}
In one of our previous works (Rakočević, 2018b), we shown that there is an analogy of genetic and a chemical code. In this note however we would like to suggest that the reverse is true, the genetic code is a kind of natural systems analogous to the chemical system of chemical elements.
\end{abstract}

In one of our previous works (Rakočević, 2018b), we shown that there is an analogy of the genetic and the chemical code; in other words, the periodic system of chemical elements is a kind of natural codes. In this note, however, we would like to suggest that the reverse is true, the genetic code is a kind of natural systems analogous to the chemical system of chemical elements. The key definition of the periodic system of chemical elements is that there is a beginning and there is an end: the beginning, as the beginning of reativity; and the end, as an end to reactivity, is the appearance of inert elements.

[In another paper, we have also shown that it is necessary to distinguish between test tube chemistry and system chemistry (Rakočević, 2019b, Box 1). Now we show in what sense it is a system, when we say that a genetic code is a system. $\left.{ }^{2}\right]$

Figure 1 was originally given in (Rakočević, 2011, Figure 10, p. 835). That what is new here is a different shading and coloring, according to the new classification. Looking at Figure 1, we are trying to discover how here, in the system of genetic code, the beginning and the end of the system are realized. As we see the beginning and ending refer to native amino acids. [For further consideration, it should be recalled that Figure 1 also follows from the periodic system of numbers, PSN (Figure 2) in that the number of atoms per row is such that it is the same as the diagonal of the periodic system.]

Whether or not an amino acid is native is determined by comparison with the key chemical function in the "head" of the amino acid, which is the carboxyl group. We see that these are the only two amino acids, aspartic and glutamic, they represent only the similarity and self-similarity to the amino acid head, they are the beginning. From the

\footnotetext{
${ }^{1}$ The test tube chemistry means a chemical reaction in any vessel, from the first human hearth, through the retorts of alchemists to modern chemical vessels in chemical laboratories and/or in technological vessels and autoclaves.

${ }^{2}$ Already in the first paper we published in an international journal, we presented an important systemic characteristic of the genetic code - a synchronous determination with chemical characteristics and the number of atoms and nucleons (Rakočević and Jokić, 1996).
} 
standpoint of self-similarity, the path to the end should be such that it includes one more functional group from the "head", which is the only remaining one - the amino group. Two amide amino acids are obtained, and they represent the end; a line from amino acids with a carboxylic group in the side chain to amino acids with an amide group in the side chain was realized.

The native state in the amino acid molecule, apart from the main functional group, is certainly the amino acid skeleton, ie. the skeleton of the "head". The skeleton of the simplest hydrocarbon, methane, is meant. This pattern is repeated with the first amino acid of the alanine stereochemical type, with alanine; with its body being only one methyl group. Hence, alanine is a native amino acid. It also represents a "beginning".

The question is which amino acid is at the end? It certainly cannot be serine, but its analogue systeine, because it is the farthest from the starting point, possesses sulfur that is present neither in the first nor in the second period but in the third. (It is the only chemical element out of five that builds twenty protein amino acids, which is in the third period and the remaining four elements are in the first and second.)

In Figure 1, the native amino acids are represented in red. Following are three other native amino acids, these are aromatic amino acids - all but one, tyrosine. Because phenylalanine has a $\mathrm{CH}_{2}$ group between head and body, it belongs to the alanine stereochemical type, in other words it has a structural pattern of a methyl group, that is, a methane molecule. Starting from it there are two ends, one is with tryptophan where besides benzene there is also a pyrrole ring; but the amino acid histidine also has an end function because it also has a six pi electron system as we explained in the paper (Rakočević, 2018a)

Three (LSR) plus four (TM KY) non-native amino acids remain, which we have referred to as "intruders" in previous work (Rakočević, 2019b, Section 2.4) and explained their uniqueness. Finally, there are four amino acids of the non-alanine stereochemical type in the far right column. tipa. ${ }^{3}$

U Tabelama 1 i 2 pokazano na koji je jedinstven način klasifikacija of Aas in Figure 1 praćene ravnotežom broja nukleona u klasama i podklasama, a sve u relaciji sa unikatnostima periodnog sistema brojeva u decimalnom brojevnom sistemu, prikazanom na slici 2. Svi rezultati, zajedno, idu u priloh našoj hipotezi da je genetski kod bio kompletan još preb iotski, i kao takav, bio je uslov za nastanak života.

Tables 1 and 2 show in which a unique way the classification of AAs in Figure 1 followed by the balance of number of nucleons in classes and subclasses; all in relation to

\footnotetext{
${ }^{3}$ For four stereochemical types of protein amino acids, see: (Popov, 1989) and (Rakočević, Jokic, 1996).
} 
the uniqueness of the periodic number system in the decimal number system, shown in Figure 2. All results, together, they support our hypothesis that the genetic code was complete yet prebiotic, and as such, was a condition for the origin of life (Rakočević, 2004).

\section{References}

Popov, E.M., 1989. Strukturnaya organizaciya belkov. Nauka, Moskva.

Rakočević, M.M., 1998a. The genetic code as a Golden mean determined system. Biosystems, 46, 283-291.

Rakočević, M.M., 2004. A harmonic structure of the genetic code. J. Theor. Biol. 229, 221-234.

Rakočević, M.M., 2011b. Genetic code as a coherent system. Neuroquantology 9 (4), 821-841.

Rakočević, M.M., 2018a. The Cipher of the Genetic Code. BioSystems 171 (2018) 31-47

Rakočević, M. M., 2018b. Analogies of Genetic and Chemical Code. Polyhedron, 153, 292-298.

Rakočević, M. M., 2019a. Protein amino acids as a complete (periodic) system. Chemia Naissensis, Vol 2, Issue 1, pp. 1-43.

Rakočević, M. M., 2019b. Genetic code as an image of the mirror image. Part I, OSF Preprints, DOI 10.31219/osf.io/xht4c.

Rakočević, M. M., 2019c. Genetic code as an image of the mirror image. Supplement 1, OSF Preprints, DOI 10.31219/osf.io/umnt3

Rakočević, M.M., Jokić, A., 1996. Four stereochemical types of protein amino acids: synchronic determination with chemical characteristics, atom and nucleon number. J. Theor. Biol. 183, 345-349. 


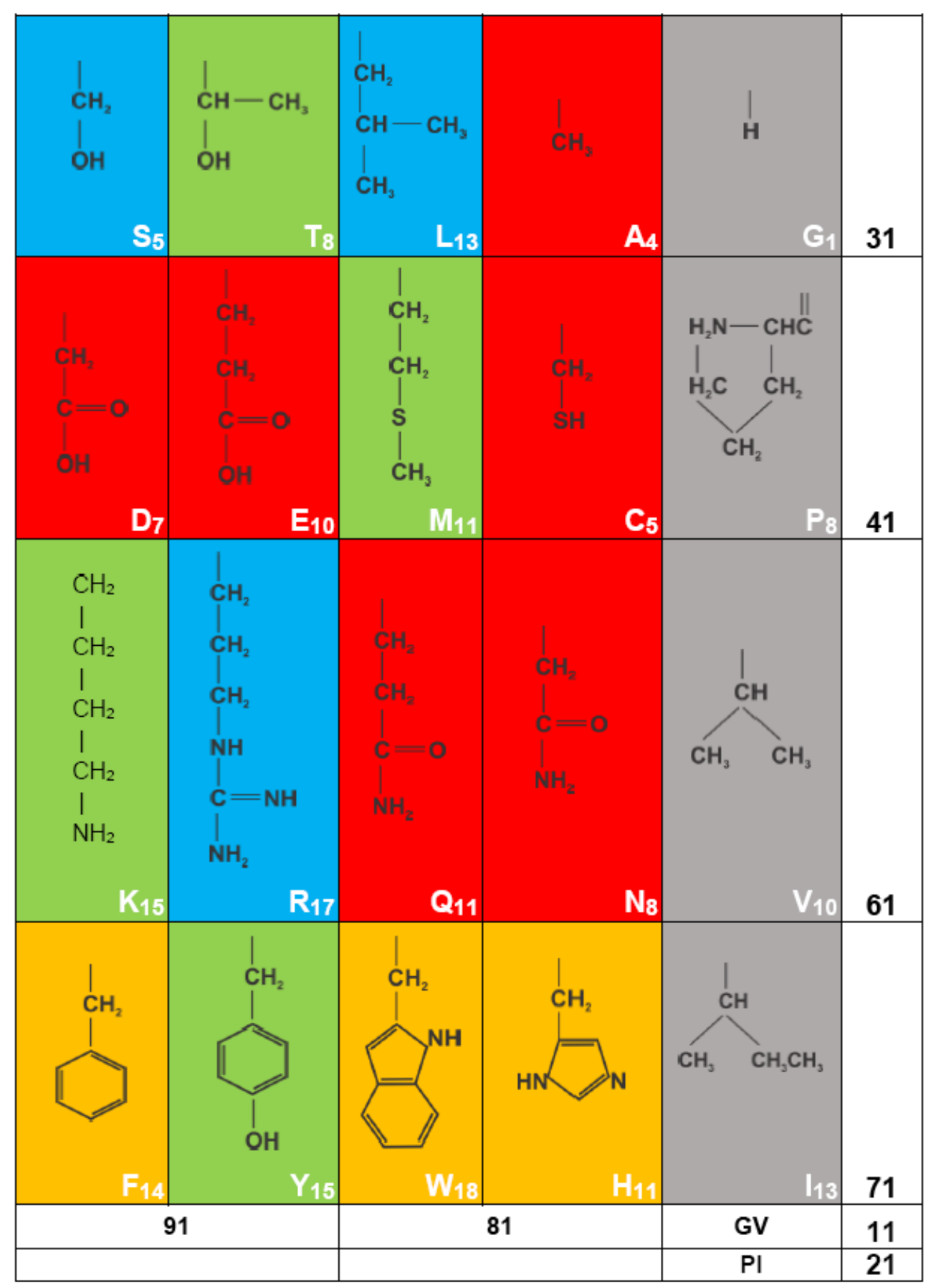

Figure 1. The chemical system of the Genetic code: $6+3$ native AAs, $3+4$ non-native AAs, altogether 16 AAs of alanine stereo-chemical type plus 4 AAs of non-alanine stereo-chemical type. Natives: red plus orange; non-natives ("intruders") blue plus green AAs and four AAs as a second class with gray color. 


\begin{tabular}{|c|c|c|c|c|c|c|c|c|c|c|c|}
\hline &.. & & & & & & & & & & \\
\hline & -21 & -20 & -19 & -18 & -17 & -16 & -15 & -14 & -13 & -12 & -11 \\
\hline & -10 & -09 & -08 & -07 & -06 & -05 & -04 & -03 & -02 & -01 & 00 \\
\hline & 01 & 02 & 03 & 04 & 05 & 06 & 07 & 08 & 09 & 10 & 11 \\
\hline (2) & 12 & 13 & 14 & 10 & $16^{-}$ & $-47^{--}$ & -18 & 19 & 20 & 21 & 22 \\
\hline (3) & 23 & 24 & 25 & $26^{\prime}$ & 27 & 28 & 29 & 30 & 31 & 32 & 33 \\
\hline (4) & 34 & 35 & 36 & 37 & 38 & 39 & 40 & 41 & 42 & 43 & 44 \\
\hline (5) & 45 & 46 & 47 & 48 & 49 & 50 & $\underline{51}$ & 52 & 53 & 54 & 55 \\
\hline (6) & 56 & 57 & 58 & 59 & 60 & 61 & 62 & 63 & 64 & 65 & 66 \\
\hline (7) & 67 & 68 & 69 & 70 & 71 & 72 & 73 & 74 & 75 & 76 & 77 \\
\hline (8) & 78 & 79 & 80 & 81 & 82 & 83 & 84 & 85 & 86 & 87 & 88 \\
\hline (9) & 89 & 90 & 91 & 92 & 93 & 94 & 95 & 96 & 97 & 98 & 99 \\
\hline (A) & $\overline{A O}$ & $\mathrm{~A} 1$ & A2 & $\mathrm{A3}$ & $\overline{A 4}$ & $\overline{A 5}$ & $\overline{A 6}$ & A7 & A8 & A9 & AA \\
\hline (B) & B1 & B2 & B3 & B4 & B5 & B6 & B7 & B8 & B9 & $B A$ & $\mathrm{BB}$ \\
\hline
\end{tabular}

Figure 2. Periodic system of the numbers taken from (Rakočević, 2011, Tab 4, p. 826) and (Rakočević, 2019a, Fig. A1, p. 28). 
Table 1. Distinctions of AAs through chemical properties and number of nucleons in distinctive classes

Green KYTM $299+$ Blue LSR $188=\mathbf{4 8 7}$

$\operatorname{Red}$ AC $62+[$ DE $132+$ NQ $130=262]=\mathbf{3 2 4}=18 \times 18$

Orange FWH $302(302+324=\mathbf{6 2 6}[\mathbf{6 2 6}+\mathbf{4 8 7}=1111+2$

Green KYTM 299 - Blue LSR $188=111$
$\operatorname{Red}(\mathrm{AC}$ DE NQ) 324 - Orange (FWH) $302=22$

Table 2. Relations of the first two numbers with the first possible (double) Boolean space triangle in PSN by generating a series of odd and even numbers (as sets of units)

$$
\begin{aligned}
& (1+22) \&(11+2) \rightarrow 23>13 \\
& 110 / 1100 \\
& (111+22) \&(1111+2) \rightarrow 133<1113 \\
& 11000 \text { / } 110000 \\
& (11111+22) \&(111111+2) \rightarrow 11133<111113 \\
& 1100000 \text { / } 11000000 \\
& (1111111+22) \&(11111111)+2 \rightarrow 1111133<11111113 \\
& \text {....... }
\end{aligned}
$$

